\title{
Absence of $t(14 ; 18)$ chromosome translocation in agricultural workers after short-term exposure to pesticides
}

\author{
VENERANDO RAPISARDA ${ }^{1}$, CATERINA LEDDA $^{1}$, SERENA MATERA ${ }^{1}$, LUCREZIA FAGO ${ }^{1}$, \\ GIORGIO ARRABITO ${ }^{2}$, LUCA FALZONE ${ }^{3}$, ANDREA MARCONI $^{1}$, MASSIMO LIBRA $^{3}$ and CARLA LORETO $^{4}$ \\ ${ }^{1}$ Section of Occupational Medicine, Department of Clinical and Experimental Medicine, University of Catania, Catania; \\ ${ }^{2}$ Prevention and Safety in the Workplace Service, Provincial Health Agency of Ragusa, Ragusa; Sections of ${ }^{3}$ General and \\ Clinical Pathology and Oncology, and ${ }^{4}$ Human Anatomy and Histology, Department of Biomedical and
}

Biotechnology Sciences, University of Catania, Catania, Italy

Received December 20, 2016; Accepted February 7, 2017

DOI: $10.3892 / \mathrm{mmr} .2017 .6385$

\begin{abstract}
Exposure to pesticides represents a potential health risk for the general population and for agricultural workers in particular. Some researchers observed that occupational exposure to pesticides is associated with risk of non-Hodgkin's lymphoma (NHL). The chromosomal translocation $\mathrm{t}(14 ; 18)$ (q32; 21 ) is one of the most common chromosomal abnormalities in NHL. The aim of this study was to detect the effects of pesticides on $t(14 ; 18)$ chromosome translocation in agricultural workers after short-term exposure. Fifty-two workers occupationally exposed to pesticides (fungicides and insecticides) and 52 non-exposed were recruited. The farm workers were on average exposed to pesticides for $\sim 3.7 \mathrm{~h}$ a day for 5 years. The frequency of BCL2-IGH $\mathrm{t}(14 ; 18)$ translocation in workers occupationally exposed to pesticides was $10 \%$ (5 of 52) vs. $8 \%$ (4 of 52) in the control group. Overall, these data suggest that no significant association between occupational exposure to pesticides and an increased frequency of the chromosomal translocation BCL2-IGH $\mathrm{t}(14 ; 18)$ in farmers was observed. However, further studies with a higher number of subjects exposed to pesticides are necessary to confirm this observation.
\end{abstract}

\section{Introduction}

Pesticides are substances or mixture of substances used for preventing, destroying, repelling or mitigating pests which include insects, rodents, weeds, as well as other unwanted organisms $(1,2)$. Hence, worldwide use of pesticides, especially in agriculture, has grown over the last years in rural areas. Extensive agricultural production includes large use

Correspondence to: Dr Caterina Ledda, Section of Occupational Medicine, Department of Clinical and Experimental Medicine, University of Catania, Via Santa Sofia 78, I-95123 Catania, Italy E-mail: cledda@unict.it

Key words: non-Hodgkin's lymphoma, BCL2, B-cell, occupational exposure, greenhouse, fungicides, insecticides, carcinogenicity, cancer of pesticides; their residues pollute the air, soil, water, plants, harvested products, equipment, clothes, as well as human and animal tissues. The applied pesticides entering the human body through breathing, swallowing and skin absorption may cause poisoning (2-4). The degree of generated damage depends on the intrinsic toxicity of the substances and the individual health status and sensitivity (2,4-6). Exposure to pesticides represents a potential health risk for the general population and for agricultural workers in particular (7-12).

Many studies have focused on the association between exposure to pesticides and cancer occurrence such as sarcoma, multiple myeloma, bladder cancer, pancreatic cancer and leukemia (13-21). Some researchers observed that occupational exposure to pesticides has been associated with risk of nonHodgkin's lymphoma (NHL) (22-24). NHL is a heterogeneous group of lymphoproliferative malignancies that can arise from B- or T-lymphocytes. Reciprocal rearrangements of B-cell immunoglobulin or T-cell receptor genes occur with oncogenes within immature lymphoid cells in the bone marrow or more mature cells in the peripheral lymphoid organs $(25,26)$. These chromosomal translocations often result in the overexpression of oncogenes and cause the cells to become malignant and proliferate in an uncontrolled way (26).

The chromosomal translocation $\mathrm{t}(14 ; 18)(\mathrm{q} 32 ; \mathrm{q} 21)$ is one of the most common chromosomal abnormalities in NHL which occurs in 70-90\% of cases of follicular lymphoma (FL), $20-30 \%$ of diffuse large B-cell lymphoma and 5-10\% of other less common subtypes (27). Furthermore, an increased prevalence of the chromosomal translocation $\mathrm{t}(14 ; 18)(\mathrm{q} 32 ; \mathrm{q} 21)$ has been detected in peripheral blood lymphocytes from individuals occupationally exposed to pesticides $(28,29)$.

The aim of this study is to detect the effects of pesticides on $\mathrm{t}(14 ; 18)$ chromosome translocation in agricultural workers after short-term exposure.

\section{Materials and methods}

Ethics statement. The research protocol was approved by the Ethics Committee of Catania University Hospital (Catania, Italy) and the written informed consent of all subjects was acquired prior to their inclusion in the study. 
Table I. Pesticides applied in the greenhouse in cultivation of tomatoes.

\begin{tabular}{llcc}
\hline $\begin{array}{l}\text { Type of } \\
\text { pesticide }\end{array}$ & \multicolumn{1}{c}{$\begin{array}{c}\text { Active } \\
\text { ingredient }\end{array}$} & $\begin{array}{c}\text { No. of } \\
\text { applications }\end{array}$ & Dose \\
\hline Fungicides & $\begin{array}{l}\text { Propamocarb } \\
\text { hydrochloride }\end{array}$ & 1 & $11 / \mathrm{ha}$ \\
& Metalaxyl-M & 2 & $31 / \mathrm{ha}$ \\
& Cyproconazole & 1 & $0.05 \mathrm{~kg} / \mathrm{ha}$ \\
Insecticides & Thiamethoxam & 1 & $0.4 \mathrm{~kg} / \mathrm{ha}$ \\
& Deltamathrin & 3 & $0.5 \mathrm{l} / \mathrm{ha}$ \\
& Acrinathrin & 1 & $0.5 \mathrm{l} / \mathrm{ha}$ \\
& Abamectin & 1 & $11 / \mathrm{ha}$ \\
\hline
\end{tabular}

Study design and pesticide exposure. This was a case-control study conducted in the province of Ragusa (Sicily, Italy) which has a population of $\sim 320,000$. This is a highly agricultural district with a large proportion of the population employed in $\sim 25,000$ farms producing fruits and vegetables in greenhouses and products derived from animal husbandry. All these activities involve the use of large quantities of pesticides. The main crops are carrots, potatoes and zucchini in open-fields and tomatoes, eggplants, peppers and zucchini in greenhouses (30).

Fifty-two workers occupationally exposed to pesticide and 52 non-exposed were recruited. Exposed workers participating in this study carry out their work with safety protective devices (SPDs): gloves, masks, overalls and protective glasses. Pesticide application was done 5-6 times/week and for 6-7 working hours. Non-exposed workers (control) did not have any contact with pesticides. Exposed ones were recruited on a seasonal basis (April to August), in the cultivation of greenhouse tomatoes. Table I reports the pesticides utilized by exposed workers. It was not possible to detect exposure biological markers with regard to pesticides employed.

A structured questionnaire investigating environmental and occupational risks was administered by trained interviewers to gather accurate data on demographics, medical history, healthcare habits and pesticide and/or other chemical exposures. Exclusion criteria were diabetes, hypertension, thyroid, liver, kidney, lung and hematological diseases.

t(14;18)-(IgH;Bcl-2) translocation. Peripheral blood samples (10 ml/subjects) were collected in vacutainer EDTA (K2) tubes (BD Biosciences, Franklin Lakes, NJ, USA). DNA was extracted from the PBMCs contained in the buffy coat according to the manufacturer's instructions.

$\mathrm{t}(14 ; 18)-(\mathrm{IgH} ; \mathrm{Bcl}-2)$ translocation, at the major breakpoint region $(\mathrm{MBR})$ and minor cluster region $(\mathrm{mcr})$, was assessed by the polymerase chain reaction (PCR) as previously reported (31). AccuPrime $^{\mathrm{TM}}$ SuperMix (Invitrogen Life Technologies, Carlsbad, CA, USA) was used to increase the specificity and sensitivity of PCR analysis. The sensitivity of our assay was $10^{-5}$.

DNA integrity of each sample was verified by amplification of a 430 bp fragment of the growth hormone $(G H)$ gene by PCR. The forward and reverse primer sequences used for $G H$ amplification were: 5'-CACCATTACATCCCACCT-3' and 5'-GCTTCTTGCTTGAGTGA-3', respectively. PCR conditions
Table II. Characteristics of study population expressed as frequency or mean $\pm \mathrm{SD}$.

\begin{tabular}{lccc}
\hline Characteristics & $\begin{array}{c}\text { Exposed } \\
(\mathrm{n})\end{array}$ & $\begin{array}{c}\text { Non-exposed } \\
(\mathrm{n})\end{array}$ & P-value \\
\hline Gender (male) & $52(100 \%)$ & $52(100 \%)$ & $\mathrm{ns}$ \\
Age (years) & $33.7 \pm 1.7$ & $34.2 \pm 1.4$ & $\mathrm{~ns}$ \\
BMI $\left(\mathrm{kg} / \mathrm{m}^{2}\right)$ & $21.8 \pm 2.1$ & $22.5 \pm 1.8$ & $\mathrm{~ns}$ \\
Smokers & $16(31 \%)$ & $17(33 \%)$ & $\mathrm{ns}$ \\
Alcohol consumption (g/day) & $17.6 \pm 8.5$ & $18.7 \pm 7.7$ & $\mathrm{~ns}$ \\
Family history & $9(17 \%)$ & $13(25 \%)$ & $\mathrm{ns}$ \\
of cancer & & & $\mathrm{ns}$ \\
Working age (years) & $6.3 \pm 2.1$ & $6.9 \pm 1.9$ & $\mathrm{~ns}$ \\
Sunlight exposure (h/day) & $4.3 \pm 1.1$ & $4.5 \pm 0.8$ & $\mathbf{< 0 . 0 0 0 1}$ \\
Exposure duration (years) & $5.1 \pm 0.8$ & 0 & $\mathbf{< 0 . 0 0 0 1}$ \\
Hours of spraying (h/day) & $3.7 \pm 1.4$ & 0 & \\
\hline
\end{tabular}

ns, not significant. Bold text, statistically significant.

used for $G H$ amplification were identical to that reported for the MBR (31).

PCR products were separated by electrophoresis on $2.5 \%$ agarose gel. Positive and negative control samples were included throughout all steps of the experimental procedures. Single bands obtained by amplification of the MBR and MCR from blood specimens were purified from the gel and then sequenced on an ABI 310 Genetic Analyzer (Perkin-Elmer, Foster City, CA, USA) as previously reported (31).

Statistical analysis. Data were summarized as mean \pm SD for continuous variables and frequencies for categorical variables. Normality was checked by Kolmogrov-Smirnov test and homogeneity of variance by Levene's test. Logistic regression was utilized to evaluate the presence of translocation $\mathrm{t}(14 ; 18)$ in workers exposed to pesticides, smokers and alcohol consumers. Data analysis was performed using GraphPad Prism version 7.0 (GraphPad Software, Inc., La Jolla, CA, USA).

\section{Results}

The exposed group presented characteristics similar to those non-exposed. In particular, all subjects were male and there were no statistically significant differences as to age, BMI, smoking habits, alcohol intake, working age and sunlight exposure.

Farm workers were on average exposed to pesticides for $\sim 3.7 \mathrm{~h}$ a day for 5 years. Table II reports the main sample characteristics; Fig. 1.

The frequency of BCL2-IGH t(14;18) translocation in workers occupationally exposed to pesticides was $10 \%$ (5 of 52) vs. $8 \%$ (4 of 52) in the control group. These results showed no significant association between occupational exposure to pesticides and an increased frequency of the chromosomal translocation BCL2-IGH $\mathrm{t}(14 ; 18)$ in farmers (Table III). 
Table III. Logistic regression $\mathrm{t}(14 ; 18)$ chromosome translocation.

\begin{tabular}{lcc}
\hline Patients & OR $(\mathrm{CI})$ & P-value \\
\hline Pesticides & 1 & $\mathrm{~ns}$ \\
$\quad$ Non-exposed & $1.01(0.94-0.08)$ & \\
Exposed & 1 & $\mathrm{~ns}$ \\
Alcohol consumption & $0.87(0.71-1.03)$ & \\
$\quad$ Non-consumers & 1 & $\mathrm{~ns}$ \\
Consumers & $0.93(0.82-1.04)$ & \\
Smoke & & \\
Non-smokers & & \\
Smokers & & \\
\hline
\end{tabular}

ns, not significant.

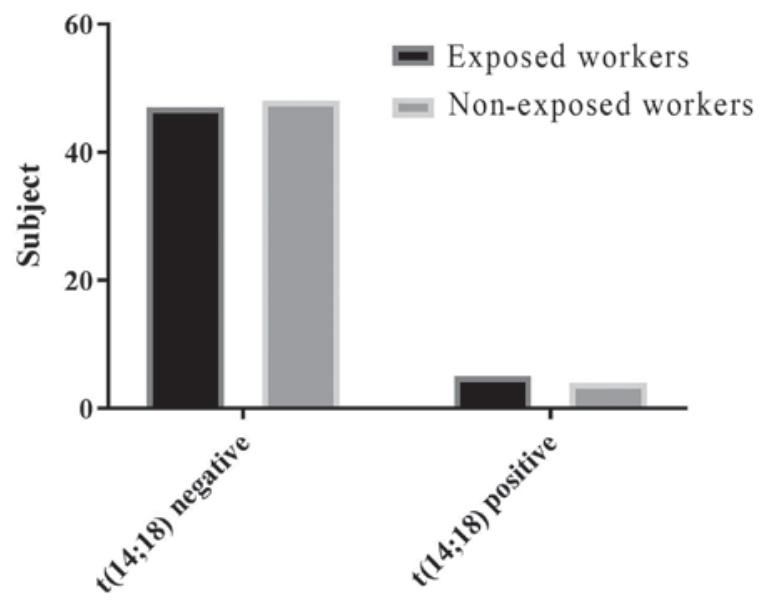

Figure 1. Frequencies for $\mathrm{t}(14 ; 18)$ chromosome translocation.

Moreover, it was not possible to assess the frequency of $t(14 ; 18)$ in relation to the types of pesticide used, because all subjects were exposed to insecticides and fungicides.

\section{Discussion}

The chromosomal translocation $\mathrm{t}(14 ; 18)(\mathrm{q} 32 ; \mathrm{q} 21)$ is one of the most common chromosomal abnormalities in NHL. This translocation involves 2 specific loci, the immunoglobulin heavy chain $(\operatorname{IgH})$ locus on chromosome $14 \mathrm{q} 32$ and the B-cell leukemia/lymphoma 2 (BCL2) locus on chromosome 18q2l (32).

During the typical translocation process, the BCL2 gene located on chromosome 18 is juxtaposed to the transcriptionally active $\mathrm{IgH}$ gene on chromosome 14, resulting in overexpression of the former. Consequently, the heightened anti-apoptotic function of BCL2 increases cell survival, which represents an early step in the malignant process of NHL (32-34).

An increased incidence of NHL has been reported among farmers and other occupational groups working with pesticides (35). Furthermore, an increased prevalence of the chromosomal translocation $\mathrm{t}(14 ; 18)(\mathrm{q} 32 ; \mathrm{q} 21)$ has been detected in peripheral blood lymphocytes from individuals occupationally exposed to pesticides $(29,36,37)$.

In a recent study conducted on 96 agricultural workers, Qaqish et al (1) found that occupational exposure to pesticides in open-field farming and insecticides used on animals, increased the frequency of the chromosomal translocation $t(14 ; 18)$. Farmers occupationally exposed to pesticides and insecticides were 13.5 times more likely to harbor $\mathrm{t}(14 ; 18)$. Instead, $63.5 \%$ (61 of 96) of farmers compared to $11.5 \%$ (11 of 96) of control ones carried the translocation [odds ratio, 13.5; 95\% confidence interval $(\mathrm{CI})=6.3-28.6]$.

In our study, the BCL2-IGH t $(14 ; 18)$ translocation frequency in workers occupationally exposed to pesticides was $10 \%$ (5 of 52) vs. $8 \%$ (4 of 52) in the control group, without significantly statistical differences.

The discrepancy of results between ours and Qaqish et al (1) can be attributed to the lesser time of exposure (50\%) compared to the latter $(10.9 \pm 7.9$ vs. $5.1 \pm 0.8$ years).

Besides, in our sample all workers availed themselves of standard SPDs, whereas in Qaqish et al (1) only $2.1 \%$ of farmers used masks and $27.1 \%$ used masks and gloves.

As shown by Qaqish et al (1), using SPDs may help prevent $t(14 ; 18)$. The risk of $t(14 ; 18)$ was significantly associated to the exposures to different kinds of pesticides: insecticides, herbicides and fumigants (28).

Chiu et al (28) observed that the use of insecticides and herbicides was associated with a 2.6- to 3-fold higher risk of $t(14 ; 18)$-positive NHL. These results are consistent with findings from previous studies in which pesticides were specifically associated with follicular NHL $(23,38-40)$, which is usually positive for the $\mathrm{t}(14 ; 18)$.

Chiu et al (28) and Schroeder et al (41) found that the risk of NHL associated with farming and exposure to dieldrin, lindane, atrazine or fungicides was associated with $\mathrm{t}(14 ; 18)$.

In Italy, the use of pesticides like dieldrin, lindane and atrazine was forbidden long ago. Moreover, exposed subjects in our study were exposed both to fungicides (propamocarb hydrochloride, metalaxyl-M, cyproconazole) and to insecticides (thiamethoxam, deltamathrin, acrinathrin and abamectin) and so the action of each could not be differentiated.

The results of our study are in line with that observed by others $(1,28)$, who detected an increased risk when insecticides and herbicides are used for a longer time and in relation with using SPDs.

We assessed the effects of potential confounding factors on the frequency of BCL2-IGH $t(14 ; 18)$ translocation detection. Firstly, alcohol consumption did not contribute to the frequency of detection, potentially due to the low rate of alcohol consumption in our study group (17.6 $\pm 8.5 \mathrm{vs.} 18.7 \pm 7.7 \mathrm{~g} /$ day for exposed and non-exposed, respectively). Additionally, we did not detect an association between the age of samples and the frequency of BCL2-IGH $t(14 ; 18)$ translocation detection $(1,29)$.

Our study as well as Roulland et al (29) and Qaqish et al (1) included subjects with median ages $<50$ years, where an association with age was detected only in samples older than 60 (42) and 70 years (43) of age. Moreover, cigarette smoking did not increase the frequency of BCL2-IGH $t(14 ; 18)$ translocation in our sample, consistent with a previous study (28). Furthermore, sunlight exposure did not show an effect on $t(14: 18)$ detection frequency, consistent with other studies (29). 
Therefore, from the results of our study it is possible to conclude that a constant use of law prescribed SPDs and time of exposure may impact on the translocation frequency in pesticide exposed workers.

Our study shall be continued with a follow-up of these workers, in order to better determine the role of 'Time of exposure' factor on gene translocation.

\section{References}

1. Qaqish BM, Al-Dalahmah O, Al-Motassem Y, Battah A and Ismail SS: Occupational exposure to pesticides and occurrence of the chromosomal translocation $\mathrm{t}(14 ; 18)$ among farmers in Jordan. Toxicol Rep 3: 225-229, 2016.

2. Bolognesi C: Genotoxicity of pesticides: a review of human biomonitoring studies. Mutat Res 543: 251-272, 2003.

3. Martínez-Valenzuela C, Waliszewski SM, Amador-Muñoz O, Meza E, Calderón-Segura ME,Zenteno E, Huichapan-Martínez J, Caba M, Félix-Gastélum R and Longoria-Espinoza R: Aerial pesticide application causes DNA damage in pilots from Sinaloa, Mexico. Environ Sci Pollut Res Int: Nov 5, 2016 (Epub ahead of print).

4. Gaikwad AS, Karunamoorthy P, Kondhalkar SJ, Ambikapathy M and Beerappa R: Assessment of hematological, biochemical effects and genotoxicity among pesticide sprayers in grape garden. J Occup Med Toxicol 10: 11, 2015.

5. Ismail AA, Rohlman DS, Abdel Rasoul GM, Abou Salem ME and Hendy OM: Clinical and biochemical parameters of children and adolescents applying pesticides. Int J Occup Environ Med 1: 132-143, 2010.

6. Patil JA, Patil AJ and Govindwar SP: Biochemical effects of various pesticides on sprayers of grape gardens. Indian J Clin Biochem 18: 16-22, 2003.

7. Saldana TM, Basso O, Hoppin JA, Baird DD, Knott C, Blair A, Alavanja MCR and Sandler DP: Pesticide exposure and self-reported gestational diabetes mellitus in the Agricultural Health Study. Diabetes Care 30: 529-534, 2007.

8. Ledda C, Fiore M, Santarelli L, Bracci M, Mascali G, D'Agati MG, Busà $\mathrm{A}$, Ferrante $\mathrm{M}$ and Rapisarda V: Gestational hypertension and organophosphorus pesticide exposure: a cross-sectional study. Biomed Res Int 2015: 280891, 2015.

9. Malekirad AA, Faghih M, Mirabdollahi M, Kiani M, Fathi A and Abdollahi M: Neurocognitive, mental health, and glucose disorders in farmers exposed to organophosphorus pesticides. Arh Hig Rada Toksikol 64: 1-8, 2013.

10. Costa C, Rapisarda V, Catania S, Di Nola C, Ledda C and Fenga C: Cytokine patterns in greenhouse workers occupationally exposed to $\alpha$-cypermethrin: an observational study. Environ Toxicol Pharmacol 36: 796-800, 2013.

11. Bolognesi C, Creus A, Ostrosky-Wegman P and Marcos R: Micronuclei and pesticide exposure. Mutagenesis 26: 19-26, 2011.

12. Sailaja N, Chandrasekhar M, Rekhadevi PV, Mahboob M, Rahman MF, Vuyyuri SB, Danadevi K, Hussain SA and Grover P: Genotoxic evaluation of workers employed in pesticide production. Mutat Res 609: 74-80, 2006.

13. La Vecchia C, Negri E, D'Avanzo B and Franceschi S: Occupation and lymphoid neoplasms. Br J Cancer 60: 385-388, 1989.

14. Brown LM, Blair A, Gibson R, Everett GD, Cantor KP, Schuman LM, Burmeister LF, Van Lier SF and Dick F: Pesticide exposures and other agricultural risk factors for leukemia among men in Iowa and Minnesota. Cancer Res 50: 6585-6591, 1990.

15. Hardell L and Eriksson M: A case-control study of non-Hodgkin lymphoma and exposure to pesticides. Cancer 85: 1353-1360, 1999.

16. Meinert R, Schüz J, Kaletsch U, Kaatsch P and Michaelis J: Leukemia and non-Hodgkin's lymphoma in childhood and exposure to pesticides: results of a register-based case-control study in Germany. Am J Epidemiol 151: 639-646, 2000.

17. Petrelli G, Figà-Talamanca I, Tropeano R, Tangucci M, Cini C, Aquilani S, Gasperini L and Meli P: Reproductive male-mediated risk: spontaneous abortion among wives of pesticide applicators. Eur J Epidemiol 16: 391-393, 2000.

18. Lockwood AH: Pesticides and parkinsonism: is there an etiological link? Curr Opin Neurol 13: 687-690, 2000.

19. Ji BT, Silverman DT, Stewart PA, Blair A, Swanson GM, Baris D, Greenberg RS, Hayes RB, Brown LM, Lillemoe KD, et al: Occupational exposure to pesticides and pancreatic cancer. Am J Ind Med 39: 92-99, 2001.
20. Brody JG, Aschengrau A, McKelvey W, Rudel RA, Swartz CH and Kennedy T: Breast cancer risk and historical exposure to pesticides from wide-area applications assessed with GIS Environ Health Perspect 112: 889-897, 2004.

21. Calvert GM, Plate DK, Das R, Rosales R, Shafey O, Thomsen C, Male D, Beckman J, Arvizu E and Lackovic M: Acute occupational pesticide-related illness in the US, 1998-1999: surveillance findings from the SENSOR-pesticides program. Am J Ind Med 45: 14-23, 2004.

22. Blair A and Zahm SH: Agricultural exposures and cancer. Environ Health Perspect 103 (Suppl 8): 205-208, 1995.

23. Chiu BC and Weisenburger DD: An update of the epidemiology of non-Hodgkin's lymphoma. Clin Lymphoma 4: 161-168, 2003.

24. Dich J, Zahm SH, Hanberg A and Adami HO: Pesticides and cancer. Cancer Causes Control 8: 420-443, 1997.

25. Schwaenen C, Wessendorf S, Kestler HA, Döhner H, Lichter P and Bentz M: DNA microarray analysis in malignant lymphomas. Ann Hematol 82: 323-332, 2003.

26. Potter JD: Toward the last cohort. Cancer Epidemiol Biomarkers Prev 13: 895-897, 2004

27. Janz S, Potter M and Rabkin CS: Lymphoma- and leukemia-associated chromosomal translocations in healthy individuals. Genes Chromosomes Cancer 36: 211-223, 2003.

28. Chiu BC, Dave BJ, Blair A, Gapstur SM, Zahm SH and Weisenburger DD: Agricultural pesticide use and risk of $\mathrm{t}(14 ; 18)$-defined subtypes of non-Hodgkin lymphoma. Blood 108: 1363-1369, 2006

29. Roulland S, Lebailly P, Lecluse Y, Briand M, Pottier D and Gauduchon P: Characterization of the $t(14 ; 18)$ BCL2-IGH translocation in farmers occupationally exposed to pesticides. Cancer Res 64: 2264-2269, 2004

30. Licciardello F, Antoci ML, Brugaletta L and Cirelli GL: Evaluation of groundwater contamination in a coastal area of south-eastern Sicily. J Environ Sci Health B 46: 498-508, 2011.

31. Libra M, Gloghini A, Malaponte G, Gangemi P, De Re V, Cacopardo B, Spandidos DA, Nicoletti F, Stivala F, Zignego AL, et al: Association of $\mathrm{t}(14 ; 18)$ translocation with HCV infection in gastrointestinal MALT lymphomas. J Hepatol 49: 170-174, 2008.

32. Nadel B, Marculescu R, Le T, Rudnicki M, Böcskör S and Jäger U: Novel insights into the mechanism of $\mathrm{t}(14 ; 18)(\mathrm{q} 32 ; \mathrm{q} 21)$ translocation in follicular lymphoma. Leuk Lymphoma 42: 1181-1194, 2001.

33. Hockenbery D, Nuñez G, Milliman C, Schreiber RD and Korsmeyer SJ: Bcl-2 is an inner mitochondrial membrane protein that blocks programmed cell death. Nature 348: 334-336, 1990.

34. Ismail SI, Sughayer MA, Al-Quadan TF, Qaqish BM and Tarawneh MS: Frequency of $\mathrm{t}(14 ; 18)$ in follicular lymphoma patients: geographical or technical variation. Int J Lab Hematol 31: 535-543, 2009.

35. Chiu BC and Blair A: Pesticides, chromosomal aberrations, and non-Hodgkin's lymphoma. J Agromed 14: 250-255, 2009.

36. Garry VF, Tarone RE, Long L, Griffith J, Kelly JT and Burroughs B: Pesticide appliers with mixed pesticide exposure: G-banded analysis and possible relationship to non-Hodgkin's lymphoma. Cancer Epidemiol Biomarkers Prev 5: 11-16, 1996.

37. Agopian J, Navarro JM, Gac AC, Lecluse Y, Briand M, Grenot P, Gauduchon P, Ruminy P, Lebailly P, Nadel B, et al: Agricultural pesticide exposure and the molecular connection to lymphomagenesis. J Exp Med 206: 1473-1483, 2009.

38. Zahm SH, Weisenburger DD, Babbitt PA, Saal RC, Vaught JB, Cantor KP and Blair A: A case-control study of non-Hodgkin's lymphoma and the herbicide 2,4-dichlorophenoxyacetic acid (2,4-D) in eastern Nebraska. Epidemiology 1: 349-356, 1990.

39. Cantor KP, Blair A, Everett G, Gibson R, Burmeister LF, Brown LM, Schuman L and Dick FR: Pesticides and other agricultural risk factors for non-Hodgkin's lymphoma among men in Iowa and Minnesota. Cancer Res 52: 2447-2455, 1992.

40. Zahm SH and Blair A: Pesticides and non-Hodgkin's lymphoma. Cancer Res 52 (Suppl 19): 5485s-5488s, 1992.

41. Schroeder JC, Olshan AF, Baric R, Dent GA, Weinberg CR Yount B, Cerhan JR, Lynch CF, Schuman LM, Tolbert PE, et al: Agricultural risk factors for $\mathrm{t}(14 ; 18)$ subtypes of non-Hodgkin's lymphoma. Epidemiology 12: 701-709, 2001.

42. Liu Y, Hernandez AM, Shibata D and Cortopassi GA: BCL2 translocation frequency rises with age in humans. Proc Natl Acad Sci USA 91: 8910-8914, 1994.

43. Hirt C, Weitmann K, Schüler F, Kiefer T, Rabkin CS, Hoffmann W and Dölken G: Circulating $t(14 ; 18)$-positive cells in healthy individuals: association with age and sex but not with smoking. Leuk Lymphoma 54: 2678-2684, 2013. 